\title{
A IMPOSSIBILIDADE JURÍDICA DA ADOÇÃO POR CASAIS HOMOAFETIVOS
}

\section{THE LEGAL IMPOSSIBILITY OF ADOPTION BY HOUSEHOLD COUPLES}

RODORIGO CHAVES MARCZUK

Acadêmico do curso de Direito - Faculdade do Litoral Paranaense - ISEPE. Guaratuba-PR. E-mail: erichistoria@gmail.com.

\section{LUCIANO RAITER}

Professor Orientador - Faculdade do Litoral Paranaense - ISEPE. Guaratuba - PR. E-mail: direito@isepe.edu.br

\section{RESUMO}

$\mathrm{Na}$ atualidade, apesar de o assunto homossexualidade vir sendo tratado com a maior naturalidade, ainda desperta preconceito em alguns grupos sociais, os quais entendem que essa minoria não faz parte de nossa sociedade. Assim como qualquer classe, os homossexuais devem ser tratados como seres humanos, com direitos na sociedade, sendo um deles, o direito a paternidade ou maternidade através da adoção. Tantas são as crianças que hoje se encontram na espera de um lar e de uma família, assim como, tantos são os casais por pessoas do mesmo sexo que aguardam ansiosos para a formação de uma família completa, ou seja, com filhos. Nesse diapasão, não há previsão legal no sistema jurídico brasileiro acerca do instituto da adoção por casais homoafetivos, mas dispensa-Ihes o procedimento equiparado ao das uniões estáveis, que está assegurado no artigo 227, caput, e §5º, 
Personalidade Acadêmica Homenageada:

Augustus B. Cochran III (Agnes Scott College)

da Constituição Federal, e no plano infraconstitucional, ficou a cargo do Estatuto da Criança e do Adolescente (Lei no 8.069/90), junto ao Código Civil, resolvendo assim, de uma só vez, dois problemas que afrontam a sociedade. Juridicamente falando, uma vez que a legislação brasileira vigente não ampara, expressamente, a adoção por pessoas do mesmo sexo, estas críticas existem na doutrina. A maior dificuldade daqueles que se opõem, é compreender as transformações ocorridas na organização social, especialmente, no tocante à constituição da família que deixou de ter como alicerce a exclusividade do matrimônio e a geração de filhos, passando a ter o amor e a afetividade, como elementos fundamentais. Observou-se que, na realidade, o preconceito constitui o principal empecilho para a sua aceitação, o qual, aos poucos, tem sido superado por alguns magistrados que, adequando o direito à realidade social, vem autorizando a adoção em favor dos homoafetivos.

PALAVRA-CHAVE: Adoção; Homossexualidade; Família; Preconceito.

\section{REFERÊNCIAS}

A VECCHIATTI, Paulo Roberto lotti. Manual da Homoafetividade: da possibilidade jurídica do casamento civil, da união estável e da adoção por casais homoafetivos. Rio de Janeiro: Forense, 2008.

DALMASSO, E.I. A Convenção sobre os direitos da criança e o princípio reitor do interesse maior da criança. Novos Estudos Jurídicos, v. 9, n. 2. p.451-460, maio/ago. 2004.

DINIZ, Maria Helena. Direito civil. São Paulo: Saraiva, 2011. v.6.

ELIAS, Roberto João. Comentários ao Estatuto da Criança e do Adolescente. São Paulo: Saraiva, 1994.

LÔBO, Paulo. Direito civil: famílias. 4 ed. São Paulo: Saraiva, 2011.

SARAIVA, João Batista Costa. Compêndio de Direto Penal Juvenil Adolescente e Ato Infracional. 4. ed. Porto Alegre: Livraria do Advogado, 2010.

SOUZA, Hália Pauliv de. Adoção é adoção. Curitiba: Juruá, 2001. 
Personalidade Acadêmica Homenageada:

Augustus B. Cochran III (Agnes Scott College)

VENOSA, Silvio de Salvo. Adoção. Direito Civil Brasileiro. São Paulo: Saraiva, 2012.

VERONESE, Josiane Rose Petry. Os direitos da criança e do adolescente. São Paulo: LTR, 1999.

VECCHIATTI, Paulo Roberto lotti. Manual da Homoafetividade: da possibilidade jurídica do casamento civil, da união estável e da adoção por casais homoafetivos. Rio de Janeiro: Forense, 2008. 